\begin{tabular}{l|l|l} 
Jurnal Eksplorasi Akuntansi \\
Vol. 2, No 1, Seri C, Februari 2020, Hal 2331-2347
\end{tabular} \mid $\begin{aligned} & \text { ISSN : 2656-3649 (Online) } \\
& \text { http://jea.ppj.unp.ac.id/index.php/jea/issue/view/19 }\end{aligned}$

\title{
ANALISIS EFEKTIVITAS DAN EFISIENSI PENGELOLAAN DANA NAGARI (STUDI PADA NAGARI DI KABUPATEN AGAM)
}

\author{
Suci Febriyanti ${ }^{1}$, Halmawati ${ }^{2}$ \\ ${ }^{1}$ Alumni Jurusan Akuntansi Fakultas Ekonomi, Universitas Negeri Padang \\ ${ }^{2}$ Jurusan Akuntansi Fakultas Ekonomi, Universitas Negeri Padang \\ *Korespondensi: sucifebriyanti22@gmail.com
}

\begin{abstract}
The research aims to determine the effectiveness and efficiency of the management of nagari funds in Agam Regency in 2015-2018 and to find out the management of nagari funds in Agam Regency in accordance with Law Number 2014 concerning Villages and Minister of Home Affairs Regulation Number 113 years 2014 on Village Financial Management. This research is a descriptive quantitative research. Data collection techniques are questionnaires, documentation and literature study. Questionnaires were distributed to guardians of the village, village staff (village secretary, village treasurer and planning committee), chair of the BPD, deputy chair of the BPD, and members of the BPD (representing one of the members) in 17 (seventeen) villages. The results of this study prove that (1) the effectiveness of 17 (seventeen) nagari can be concluded to be effective. While the efficient level of 17 (seventeen) nagari can be concluded to be still inefficient. (2) the results of the validity and reliability test show that overall the statement items used in the questionnaire showed very good results, meaning that the management of the nagari funds in Agam Regency was in accordance with Law Number 2014 concerning Villages and Minister of Domestic Affairs Number 113 of 2014 concerning Village Financial Management.
\end{abstract}

Keywords: village financial management; effectiveness; efficiency

How to cite (APA $6^{\text {th }}$ style):

Febriyanti, Suci; Halmawati. (2020). Analisis Efektifitas dan Efisiensi Pengelolaan Dana Nagari (Studi Pada Nagari di Kabupaten Agam). Jurnal Eksplorasi Akuntansi. 2(1), Seri C, 2331-2347.

\section{PENDAHULUAN}

Undang-undang desa telah menempatkan nagari sebagai ujung tombak pembangunan dan peningkatan kesejahteraan masyarakat. Nagari diberikan kewenangan dan sumber dana yang memadai agar pemerintah nagari dapat mengelola potensi yang dimiliki nagari guna meningkatkan ekonomi dan kesejahteraan masyarakat. Dimana dalam Undang-undang Nomor 6 tahun 2014 Pasal 1 tentang Desa menjelaskan bahwa desa merupakan kesatuan masyarakat hukum yang memiliki batas wilayah yang berwenang untuk mengatur dan mengurus urusan 
pemerintahan, kepentingan masyarakat setempat berdasarkan prakarsa masyarakat, hak asal usul, dan/atau hak tradisional yang diakui dan dihormati dalam sistem pemerintahan NKRI.

Secara normatif nagari merupakan istilah lain dari desa. Namun, desa tidak sama dengan nagari. Nagari merupakan sistem pemerintahan yang lahir, hidup dan berakar dalam kehidupan masyarakat hukum adat Minangkabau (pusako, 2013). Perbedaan anatara nagari dan desa dapat dilihat dari pengertian antara nagari dan desa. Berdasarkan Undang-undang Nomor 6 tahun 2014 tentang Desa, desa adalah desa dan desa adat atau yang disebut dengan nama lain, selanjutnya disebut desa, adalah kesatuan masyarakat hukum yang memiliki batas wilayah yang berwenang untuk mengatur dan mengurus urusan pemerintahan, kepentingan masyarakat setempat berdasarkan prakarsa masyarakat, hak asal usul, dan/atau hak tradisional yang diakui dan dihormati dalam sistem pemerintahan Negara Kesatuan Republik Indonesia.

Sedangkan nagari adalah kesatuan masyarakat hukum adat secara geneolgis dan historis, memiliki batas-batas dalam wilayah tertentu, memililki harta kekayaan sendiri, berwenang memilih pemimpinannya secara musyawarah serta mengatur dan mengurus kepentingan masyarakat setempat berdasarkan filosofi dan sandi adat, Adat Basandi Syara' - syara' Basandi Kitabullah dan/atau berdasarkan asal ususl dan adat istiadat setempat dalam wilayah Provinsi Sumatera Barat (Peraturan Daerah Provinsi Sumatera Barat Nomor 7 tahun 2018 tentang nagari). Dan bagian dari wilayah nagari disebut jororng/kororng/kampung (Peraturan Daerah Provinsi Sumatera Barat Nomor 7 tahun 2018 tentang nagari).

Dalam mengelola keuangan nagari harus berlandaskan kepada azaas-azas yang sudah ditetapkan oleh pemerintah melalui Peraturan Menteri Dalam Negeri Nomor 113 tahun 2014 tentang Pengelolaan Keuangan Desa Pasal 2 ayat (1) yang menyatakan bahwa "keuangan desa dikelola berdasarkan azas-azas transparan, akuntabel, partisipatif serta dilakukan dengan tertib dan disiplin anggaran", dengan demikian pemerintahan nagari khususnya aparatur nagari memiliki tanggung jawab dalam pengelolaan keuangan nagari secara efektif guna menjalankan pembangunan yang tepat sasaran dan efisiensi. Pengelolaan dana nagari dilakukan oleh wali nagari dengan dibantu oleh perangkat nagari yaitu, sekretaris nagari, bendahara nagari, kepala seksi masing-masing bidang terkait dengan pengelolaan dana nagari dan BPD. Tidak hanya perangkat nagari, tetapi juga ada jorong yang dipimpin oleh wali jororng yang juga ikut serta dalam pelaksanaan pengelolaan dana nagari. peran jorong disini adalah sebagai pelaksana teknis kegiatan di dalam kegiatan/program yang dijalankan/diprogramkan.

Realisasi penggunaan dana desa seringkali tidak sesuai dengan target dan pencapaiannya selama ini masih memerlukan penyempurnaan. Dalam berita antarnews Sumbar menyebutkan bahwa tercatata sebesar Rp 3,56 miliar dana desa di daerah Kabupaten Agam tidak terealisasi pada tahun 2018 akibat program tidak tuntas. Di Desa Deli Serdang, kepala desanya divonis terbukti melakukan tindakan korupsi terhadap dana alokasi desa, sehingga nantinya tujuan dari rencana desa tidak tercapai dengan maksimal. Dana desa yang mulai diimplementasikan sejak tahun 2015 dan berjalan hingga kini, untuk realisasi tahun 2015 mencapai 100\% dari target, tahun 2016 mencapai 99,4\$ dari target, tahun 2017 mencapai 99,6\% dari target, tahun 2018 mencapai 99,77 \% dari target, dan tahun 2019 hingga bulan Agustus tercatat menacapai 60,29 \% dari target (Katadata, 2019).

Tugas untuk merencanakan, mengelola, dan mengawal dana nagari ke depan akan semakin berat. Selain itu, regulasi yang disusunpun menghasilan sistem pengelolaan dana nagari yang efektif, efisien, dan akuntabel, sehingga tujuan pemerintah melalui pengalokasian dana nagari dapat terwujud. Oleh sebab itu, diperlukan penguatan kapasitas kelembagaan dan sumber daya manusia, baik aparatur pemerintah nagari, masyarakat, maupun tenaga pendampingan desa 
serta perbaikan transparansi, akuntabilitas, dan pengawasan dalam pengelolaan dana nagari dan keuangan nagari.

Tidak hanya itu, pengukuran kinerja juga sangat penting untuk menilai akuntabilitas organisasi oleh manajer dalam menghasilkan pelayanan publik yang lebih baik. Pengukuran kinerja sektor publik dilakukan untuk memenuhi tiga maksud, yaitu untuk membantu memperbaiki kinerja pemerintah, untuk pengalokasian sumber daya dan pembuat keputusan, dan untuk mewujudkan pertanggungjawaban publik dan memperbaiki komunikasi kelembagaan (Mardiasmo, 2009:121).

Menurut Mardiasmo (2009:131) mengungkapkan value for money merupakan konsep pengelolaan organisasi sektor publik yang mendasarkan pada tiga elemen utama, yaitu ekonomi, efisien, dan efektivitas. Ekonomi merupakan perbandingan input dengan input value yang dinyataka dalam satuan moneter. Efisiensi merupakan perbandingan output/input yang dikaitkan dengan standar kinerja atau target yang telah ditetapkan. Efektifitas merupakan perbandingan outcome dengan output. Nagari dikatakan telah melaksanakan kegiatan dengan value yang tinggi ketika suatu kegiatan yang dilaksanakan di nagari telah mencapai tujuannya secara efisien dan tidak ada pemborosan dana nagari sehingga dapat mendorong peningkatan kesejahteraan masyarakat nagari. Apabila value nagari bertambah, maka visi membangun Indonesia dari pinggiran dengan memperkuat daerah-daerah dan desa dalam kerangka Negara Kesatuan sebagaimana yang terdapat dalam nawacita akan dapat terwujud dengan baik.

Sesuai visi membangun Indonesia dari pinggiran sebagaimana yang terdapat dalam nawacita, dimana dana desa bersumber dari APBN yang diperuntukkan bagi nagari yang ditransfer melalui APBD Kabupaten dan diprioritaskan untuk pelaksanaan pembangunan dan pemberdayaan masyarakat nagari. Menteri Dalam Negeri Bapak Tjahjo Kumolo, dalam acara Rapat Koordinasi Nasional (Rakornas) Program Pembinaan Penyelenggaraan Pemerintah Desa Pusat dan Daerah tahun 2018 meminta agar pemerintah desa mengefektifkan pembangunan dan pemanfaatan dana desa untuk meningkatkan kesejahteraan rakyat.

Adapun efektivitas dana nagari adalah tercapainya tujuan dari pengalokasian dana nagari. sedangakn efisiensi dalam kegiatan nagari mengandung makna nagari mampu menghasilkan output yang lebih banyak dengan menggunakan input yang telah direncanakan atau mampu menghasilkan output sebagaimana direncanakan dengan menggunakan input yang lebih sedikit. Tujuan dari mengukur tingkat efektifitas dan efisiensi pengelolaan dana nagari adalah dapat memberikan bukti bahwa dana nagari yang diterima, disalurkan dan direalisasikan sesuai dengan tujuan target atau prioritas yang telah ditetapkan oleh pemerintah untuk setiap dana nagari yang diberikan kepada pemerintah daerah. Tidak saja menyerap dana yang dialokasikan, tetapi juga merealisasikan dana nagari sesuai dengan tujuan dan targetnya.

Monitoring dalam pengelolaan dana nagari dilakukan agar alokasi penyaluran dan realisasi dana nagari sesuai dengan program dan penyerapan mencapai 100 persen. Jika pemerintah daerah tidak bisa menyalurkan dana nagari tahap I dari RKUD (Rekening Kas Umum Daerah) ke RKD (Rekening Kas Desa) dalam batas waktu yang telah ditetapkan, maka nagari tidak menerima dana nagari tahap I. Itu berarti, nagari telah kehilangan dana nagari sebesar 20 persen dari pagu yang dianggarkan. Salah satu penyebab banyaknya pemerintah Kabupaten belum mencairkan dana desa adalah karena belum ditetapkannya APBDesa, padahal seperti yang ditentukan dalam Peraturan Menteri Keuangan (PMK) Nomor 225/PMK.07/2017 persyaratan pencairan dana desa dari RKUD ke RKD adalah adanya penetapan APBDesa. Pada tahun 2018, tepatnya tanggal 13 Mei 2018 merupakan batas akhir bagi pemerintah daerah menyalurkan dana desa tahap I sebesar 20 persen dari RKUD (Rekening Kas Umum Daerah) ke 
RKD (Rekening Kas Desa). Namun banyak desa yang belum menyalurkan dana desa tahap I dan beberapa Kabupaten berhasil mencairkan dana desa ke seluruh desa yang ada ditengah situasi yang mengkhawatirkan saat itu. Salah satu Kabupaten itu adalah Kabupaten Agam. Kabupaten ini telah mencairkan dana desa tahap I ke 82 nagari yang ada. Kabupaten ini juga telah menyalurkan dana desa tahap II (Yosnov, 2018).

Hall dalam Tangkilisan (2005:67) mengartikan bahwa dengan tingkat sejauh mana suatu organisasi merealisasikan tujuannya, semua konsep tersebut hanya menunjukkan pada pencapaian tujuan organisasi. Agris dalam Tangkilisan (2005:68) yang menyatakan "organizational effectiveness then is balanced organization optimal emphasis upon achieving object solving competence and human energy utilization" atau dengan kata lain efektivitas organisasi adalah keseimbangan atau pendekatan secara optimal pada pencapaian tujuan, kemampuan dan pemanfaatan tenaga manusia. Sondang (2002) berpendapat efektivitas adalah pemanfaatan sumber daya, sarana dan prasarana dalam jumlah tertentu yang secara sadar ditetapkan sebelumnya untuk menghasilkan sejumlah barang dan jasa dalam kegiatan yang dilaksanakan. Efektivitas akan menunjukkan keberhasilan dari ketercapaian tujuan dan sasaran yang diharapkan. Jika hasil kegiatan semakin mendekati atau mencapai sasaran dan tujuan berarti efektivitas dari kegiatan tersebut semakin tinggi. Yesiska (2017) menyebutkan dengan adanya dana nagari yang menitikberatkan pada pembangunan masyarakat, nagari diharapkan mampu mendorong penanganan beberapa permasalahan yang dihadapi oleh masyarakat nagari.

Riset Agustin et.al (2017) mencoba memotret pertanggungjawaban dan pelaporan keuangan nagari di kabupaten Pasaman Barat. Riset tersebut menemukan bahwa seluruh nagari di kabupaten Pasaman Barat telah rutin menyampaikan laporan pertanggung jawaban pelaksanaan APBNagari setiap tahunnya ke pemerintah kabupaten Pasaman Barat. Nagari di kabupaten Pasaman Barat juga mampu menyampaikan laporan realisasi APBNagari tepat pada waktunya, serta telah melampirkan seluruh dokumen yang dipersyaratkan (laporan kekayaan nagari, laporan program pemerintah pusat dan pemerintah daerah yang masuk ke nagari. Riset Kurnia et.al (2019) menemukan bahwa desa-desa di kecamatan Luhak Nan Duo kabupaten Pasaman Barat telah menerapkan prinsip transparansi dan akuntabilitas pada tahap perencanaan, pelaksanaan, penatausahaan, pelaporan, dan pertanggung jawaban dana desa, sebagaimana diamantkan dalam Permedagri Nomor 113 Tahun 2014 tentang Pengelolaan Keuangan. Kelemahan pengelolaan dana desa terletak pada masih adanya keterlambatan pada waktu membuat perencanaan, serta saat melaporkan dan mempertanggung jawabkan anggaran desa tersebut kepada Bupati.

Publikasi kedua riset di atas menginspirasi penulis untuk melakukan riset serupa di kabupaten Agam. Secara khusus tujuan penelitian ini adalah untuk mengetahui tingkat efektivitas dan efisiensi pengelolaan dana nagari di Kabupaten Agam tahun 2015-2018 dan mengetahui pengelolaan dana nagari di Kabupaten Agam telah sesuai dengan Undang-Undang Nomor 6 tahun 2014 dan Peraturan Menteri Dalam Negeri Nomor 113 tahun 2014 tentang Pengelolaan Keuangan Desa. Oleh karena itu peneliti ingin melakukan penelitian ini pada Nagari di Kabupaten Agam dengan judul "Analisis Efektivitas dan Efisiensi Pengelolaan Dana Nagari (Studi Pada Nagari di Kabupaten Agam)".

\section{REVIU LITERATUR DAN HIPOTESIS \\ Teori Agensi}

Menurut Jensen dan Smith (1984) teori agensi menyangkut hubungan kontraktual antara dua pihak yaitu principals dan agents. Pihak principals adalah pihak yang memberikan mandat kepada pihak lain, yaitu agents untuk melakukan semua kegiatan atas nama principals dalam 
kapasitasnya sebagai pengambil keputusan. Dalam hal pemberian dana desa oleh pemerintah pusat (principals) kepada pemerintah desa (agents), dimana hubungan kontrak yang dimaksud adalah pendelegasian wewenang kepada agent untuk mengelola dana desa secara bertanggung jawab kepada pemerintah pusat dan menjadi kepanjangan dari pemerintah pusat sebagai pemberi amanah dalam membangun Indonesia dari pinggiran dengan memperkuat daerah-daerah dan desa dalam kerangka NKRI. Teori agensi memandang bahwa pemerintah desa yaitu kepala desa dan aparat desa lainnya sebagai agents bagi masyarakat desa akan bertindak dengan penuh kesadaran bagi kepentingan mereka sendiri. Sedangkan hubungan kontrak antara pemerintah desa dengan masyarakat desa adalah pemerintah desa melakukan pengelolaan dana desa bersama masyarakat desa secara bertanggung jawab kepada pemerintah pusat yang telah membuat Peraturan Menteri Dalam Negeri Nomor 113 tahun 2014 tentang Pengelolaan Keuangan Desa.

Berdasarkan teori agensi, pengelolaan pemerintah desa harus diawasi untuk memastikan bahwa pengelolaan dana desa dilakukan dengan penuh kepatuhan kepada berbagai peraturan dan ketentuan yang berlaku seperti Peraturan Menteri Dalam Negeri Nomor 113 tahun 2014 tentang Pengelolaan Keuangan Desa, serta memperhitungkan efisiensi atas dana yang akan dikelola agar penggunaan dana desa dan tujuan adanya dana desa dapat tercapai maksimal, menggunakan dana tersebut untuk kegiatan yang tepat sasaran, agar penggunaan anggaran tepat guna.

\section{Pengelolaan Dana Desa}

\section{Dana Desa}

Menurut Peraturan Pemerintah Nomor 6 tahun 2014 tentang dana desa, dana desa adalah dana yang bersumber dari Anggaran Pendapatan dan Belanja Negara yang diperuntukkan bagi desa yang ditransfer melalui Anggaran Pendapatan dan Belanja Daerah Kabupaten/Kota dan digunakan untuk membiayai penyelenggaraan pemerintahan, pelaksanaan pembangunan, pembinaan kemasyarakatan, dan pemberdayaan masyarakat. Dana desa dapat digunakan antara lain untuk pembangunan pelayanan dasar pendidikan, kesehatan, infrastruktur, dan pengentasan kemiskinan. Besaran dana desa setiap desa dihitung berdasarkan jumlah penduduk desa, luas wilayah, angka kemiskinan desa, dan tingkat kesulitan geografis dengan bobot 30\% untuk jumlah penduduk Kabupaten, 20\% untuk luas wilayah Kabupaten, dan 50\% untuk angka kemiskinan Kabupaten.

\section{Pengelolaan Dana Desa}

Menurut Peraturan Menteri Dalam Negeri Nomor 113 tahun 2014 tentang Pedoman Pengelolaan Keuangan Desa, menjelaskan bahwa pengelolaan keuangan desa adalah keseluruhan kegiatan yang meliputi perencanaan, penganggaran, penatausahaan, pelaporan, pertanggung jawaban, dan pengawasan keuangan desa. Adapun proses pengelolaan keuangan desa berdasarkan Peraturan Menteri Dalam Negeri Nomor 113 tahun 2014 yaitu :

\section{a. Perencanaan}

Secara umum, perencanaan keuangan adalah kegiatan untuk memperkirakan pendapatan dan belanja dalam kurun waktu tertentu di masa yang akan datang. Perencanaan keuangan desa dilakukan setelah tersusunnya Rencana Pembangunan Jangka Menengah (RPJM) Desa dan Rencana Kerja Pemerintah (RKP) Desa yang menjadi dasar untuk menyusun APBDesa yang merupakan hasil dari perencanaan keuangan desa. Perencanaan keuangan desa yang telah diatur di dalam Peraturan Menteri Dalam Negeri Nomor 113 tahun 2014. 
b. Pelaksanaan

Menurut Peraturan Menteri Dalam Negeri Nomor 113 tahun 2014 Pasal 24 s/d Pasal 34 tentang Pengelolaan Keuangan Desa, dalam pelaksanaan APBDesa harus memperhatikan pendapatan desa yang berhubungan seperti :

1) Semua penerimaan dan pengeluaran desa dalam rangka pelaksanaan kewenangan desa dilaksanakan melalui rekening kas desa.

2) Khusus bagi desa yang belum memiliki pelayanan perbankan di wilayahnya maka peraturannya ditetapkan oleh Pemerintah Kabupaten.

3) Semua penerimaan dan pengeluaran desa harus didukung oleh bukti yang lengkap dan sah.

4) Pemerintah desa dilarang melakukan pungutan sebagai penerimaan desa selain yang ditetapkan dalam peraturan desa.

5) Bendahara dapat menyimpan uang dalam kas desa pada jumlah tertentu dalam rangka memenuhi kebutuhan operasional pemerintah desa.

c. Penatausahaan

Penatausahaan merupakan rangkaian kegiatan yang dilakukan secara sistematis (teratur dan masuk akal/logis) dalam bidang keuangan berdasarkan prinsip, standar, serta prosedur tertentu sehingga informasi aktual (informasi yang sesungguhnya) berkenaan dengan keuangan dapat segera diperoleh. Penatausahaan keuangan desa yang telah diatur di dalam Peraturan Menteri Dalam Negeri Nomor 113 tahun 2014 Pasal 35 tentang Pengelolaan Keuangan Desa.

d. Pelaporan

Pelaporan adalah kegiatan yang dilakukan untuk menyampaikan hal-hal yang berhubungan dengan hasil pekerjaan yang telah dilakukan selama satu periode tertentu sebagai bentuk pelaksanaan tanggung jawab (pertanggungjawaban) atas tugas dan wewenang yang diberikan. Pada tahap ini, Pemerintah Desa menyusun laporan realisasi pelaksanaan APBDesa setiap semester yang disampaikan kepada Bupati/Walikota. Pelaporan keuangan desa yang telah diatur di dalam Peraturan Menteri Dalam Negeri Nomor 113 tahun 2014 tentang Pengelolaan Keuangan Desa.

e. Pertanggungjawaban

Pertanggungjawaban pengelolaan keuangan desa dilakukan setiap akhir tahun anggaran yang disampaikan kepada Bupati dan di dalam Forum Musyawarah Desa. Pertanggungjawaban keuangan desa yang telah diatur di dalam Peraturan Menteri Dalam Negeri Nomor 113 tahun 2014 tentang Pengelolaan Keuangan Desa.

\section{Anggaran Pendapatan dan Belanja Desa (APBDesa)}

Menurut Peraturan Menteri Dalam Negeri Nomor 37 tahun 2007 pasal 1 ayat (3) tentang Pedoman Pengelolaan Keuangan Desa, Anggaran Pendapatan dan Belanja Desa adalah rencana keuangan tahunan pemerintahan desa yang dibahas dan disetujui bersama oleh pemerintah desa dan Badan Permusyawaratan Desa dan ditetapkan dengan peraturan desa. Menurut Peraturan Menteri Dalam Negeri Nomor 37 tahun 2007 pasal 4 tentang Pedoman Pengelolaan Keuangan Desa, bahwa APBDesa terdiri dari:

a. Pendapatan Desa

Pendapatan desa merupakan semua penerimaan uang melalui rekening desa yang menjadi hak desa dalam 1 (satu) tahun anggaran yang tidak perlu dibayar kembali oleh desa. Pendapatan desa diklasifikasikan menurut kelompok dan jenis sumber pendapatan desa yang diatur dalam Undang-Undang Nomor 6 tahun 2014 Pasal 71. 


\section{b. Belanja Desa}

Berdasarkan Peraturan Pemerintah Nomor 43 tahun 2014 pasal 100, mengatakan bahwa belanja desa yang ditetapkan dalam APBDesa digunakan dengan ketentuan paling sedikit 70\% (tujuh puluh persen) dari jumlah anggaran belanja desa digunakan untuk mendanai penyelenggaraan pemerintahan desa, pelaksanaan pembangunan desa, pembinaan kemasyarakatan desa, dan pemberdayaan masyarakat desa; dan paling sedikit 30\% (tiga puluh persen) dari jumlah anggaran belanja desa digunakan untuk penghasilan tetap dan tunjangan kepala desa dan perangkat desa, operasional pemerintah desa, tunjangan dan operasional Badan Permusyawaratan Desa, dan intensif rukun tetangga dan rukun warga. Sedangkan dalam Peraturan Menteri Dalam Negeri Nomor 113 tahun 2014 tentang Pengelolaan Keuangan Desa, Bab IV Bagian Kedua ialah merupakan semua proses pengeluaran yang dilakukan oleh desa. Belanja desa adalah kewajiban desa dalam satu tahun anggaran yang tidak akan diperoleh pembayarannya kembali oleh desa.

c. Pembiayaan Desa

Pembiayaan desa meliputi semua penerimaan yang perlu dibayar kembali dan/atau pengeluaran yang akan diterima kembali, baik pada tahun anggaran yang bersangkutan maupun pada tahun-tahun anggaran berikutnya.

\section{Penyusunan Rancangan APBDesa}

Pemerintah desa wajib menyususn APBDesa, Menurut Peraturan Menteri Dalam Negeri Nomor 37 tahun 2007 tentang Pedoman Pengelolaan Keuangan Desa, kepala desa yang terpilih dan dilantik paling lambat 3 (tiga) bulan ia wajib membuat Rencana Pembangunan Jangka Menengah Desa (RPJMD) untuk jangka waktu 5 (lima) tahun yang berisi tentang penjabaran visi dan misinya. Kepala desa bersamaan Badan Permusyawaratan Desa (BPD) menyusun Rencana Kerja Pembangunan Desa (RPJDesa) yang merupakan penjabaran dari RPJMDesa berdasarkan hasil musyawarah Rencana Pembangunan Desa.

Selanjutnya sekretaris menyusun rancangan Peraturan Desa tentang APBDesa berdasarkan RKPDesa. Selanjutnya sekretaris desa menyampaikan Rancangan Peraturan Desa tentang APBDesa kepada kepala desa untuk memperoleh persetujuan. Kemudian kepala desa menyampaikan Rancangan Peraturan Desa kepada BPD untuk dibahas bersama dalam rangka memperoleh persetujuan bersama. Rancangan Peraturan Desa tentang APBDesa yang telah disetujui bersama sebelum ditetapkan oleh kepala desa paling lambat 3 (tiga) hari kerja disampaikan kepada Bupati harus menetapkan evaluasi rancangan APBDesa paling lama 20 (dua puluh) hari kerja. Jika hasil evaluasi tentang APBDesa tidak sesuai dengan kepentingan umum dan peraturan perundang-undangan yang lebih tinggi, kepala desa bersama BPD melakukan penyempurnaan paling lama 7 (tujuh) hari kerja terhitung sejak diterimanya hasil evaluasi.

\section{Pelaksanaan APBDesa}

Berdasarkan Peraturan Menteri Dalam Negeri Nomor 37 tahun 2007 pasal 8 tentang Pedoman Pengelolaan Keunagan Desa, pelaksanaan APBDesa harus memenuhi ketentuan berikut ini : hal yang berkaitan dengan pendapatan desa dilakukan melalui rekening kas desa; bagi desa yang belum memiliki pelayanan perbankan di wilayahnya maka pengaturannya diserahkan kepada daerah; program dan kegiatan yang masuk desa merupakan sumber penerimaan dan pendapatan desa dan wajib dicatat dalam APBDesa; setiap pendapatan desa harus didukung oleh bukti yagn lengkap dan sah; pemungutan pendapatan desa diintensikan oleh kepala desa; tidak dibenarkan 
melakukan pungutan oleh pemerintah desa selain dari yang ditetapkan dalam peraturan desa; pengembalian atas kelebihan pendapatan desa dilakukan dengan membebankan pada pendapatan desa yang terjadi dalam tahun yang sama; membebankan pengembalian kelebihan pendapatan desa yang terjadi pada tahun-tahun sebelumnya pada belanja tidak terduga; dan bukti pendukung yang sah dan lengkap atas pengembalian tersebut.

\section{Perubahan APBDesa}

Berdasarkan Peraturan Menteri Dalam Negeri Nomor 37 tahun 2007 pasal 11 tentang Pedoman Pengelolaan Keuangan Desa, bahwa perubahan APBDesa dapat dilakukan apabila terjadi: keadaan yang menyebabkan harus dilakukan pergeseran antar jenis belanja, dapat dilakukan dengan cara merubah peraturan desa tentang APBDesa; keadaan yang menyebabkan sisa lebih perhitungan anggaran (Silpa) tahun sebelumnya harus digunakan dalam tahun berjalan; keadaan darurat; dan keadaan luar biasa. Perubahan APBDesa hanya dapat dilakukan 1 (satu) kali dalam 1 (satu) tahun anggaran, kecuali dalam keadaan luar biasa. Tata cara pengajuan perubahan APBDesa adalah sama dengan tata cara penetapan pelaksanaan APBDesa.

\section{Penatausahaan dan Pertanggungjawaban Keuangan Desa}

Penatausahaan penerimaan wajib dilakukan oleh bendahara desa dengan menggunakan buku kas umum, buku kas pembantu perincian objek penerimaan, dan buku kas harian pembantu. Menurut Sujarweni (2015) bendahara harus mengeluarkan Laporan Pertanggungjawaban (LPJ) penerimaan pada tanggal 10 (sepuluh) bulan berikutnya, disertai lampiran buku kas umum, buku kas pembantu perincian objek penerimaan, dan bukti penerimaan lainnya yang sah.

Dokumen penatausahaan pengeluaran harus disesuaikan pada Peraturan Desa tentang APBDesa atau Peraturan Desa tentang Perubahan APBDesa melalui pengajuan Surat Permintaan Pembayaran (SPP) yang harus disetujui oleh kepala desa melalui Pelaksana Teknis Pengelolaan Keuangan Desa (PTPKD). Bendahara harus mengeluarkan Laporan Pertanggungjawaban (LPJ) pengeluaran pada tanggal 10 (sepuluh) bulan berikutnya, disertai dengan lampiran buku kas umum, buku kas pembantu perincian objek pengeluaran yang disertai dengan bukti-bukti pengeluaran yang sah, dan bukti atas penyetoran PPN dan PPh ke kas negara.

\section{Pertanggungjawaban Pelaksanaan APBDesa}

Menurut Peraturan Menteri Dalam Negeri Nomor 37 tahun 2007 pasal 16, Rancangan Peraturan Desa tentang Pertanggungjawaban Pelaksanaan APBDesa dan Rancangan Keputusan Kepala Desa tentang Pertanggungjawaban Kepala Desa akan disusun oleh sekretaris desa dan akan disampaikan kepada kepala desa untuk dibahas bersama BPD. Rancangan Peraturan Desa tentang Pertangungjawaban Pelaksanaan APBDesa dapat ditetapkan menjadi Peraturan Desa dengan persetujuan kepala desa dan BPD, yang akan disampaikan paling lambat 1 (satu) bulan setelah tahun anggaran berakhir. Peraturan Desa tentang Pertanggungjawaban Pelaksanaan APBDesa dan Keputusan Kepala Desa tentang Keterangan Pertanggungjawaban Kepala Desa disampaikan kepada Bupati melalui camat, disampaikan paling lambat 7 (tujuh) hari setelah Peraturan Desa ditetapkan.

\section{Value for Money}

Menurut Mardiasmo (2009:132) value for money merupakan konsep pengelolaan organisasi sektor publik yang mendasarkan pada tiga elemen utama, yaitu ekonomi, efisiensi, dan efektivitas. Ekonomi merupakan pemerolehan input dengan kualitas dan kuantitas tertentu 
pada harga yang terendah. Dan ekonomis merupakan perbandingan input dengan input value yang dinyatakan dalam satuan moneter. Efisiensi merupakan pencapaian output yang maksimum dengan input tertentu untuk penggunaan input yang terendah untuk mencapai output tertentu. Dan efisiensi merupakan perbandingan output/input yang dikaitkan dengan standar kinerja atau target yang telah ditetapkan. Efektivitas merupakan tingkat pencapaian hasil program dengan target yang ditetapkan. Secara sederhana efektivitas merupakan perbandingan outcome dengan input.

Tujuan yang dikehendaki oleh masyarakat mencakup pertanggungjawaban mengenai pelaksanaan value for money, yaitu ekonomi (hemat cermat) dalam pengadaan dan alokasi sumber daya, efisiensi (berdaya guna) dalam penggunaan sumber daya dalam arti penggunaannya diminimalkan dan hasilnya dimaksimalkan (maximizing benefits and minimizing costs), serta efektif (berhasil guna) dalam arti mencapai tujuan dan sasaran.

\section{Efektivitas dan Efisinesi Pengelolaan Dana Nagari}

Pengelolaan dana desa sebagaimana dijelaskan pada Peraturan Menteri Dalam Negeri Nomor 113 tahun 2014 tentang Pedoman Pengelolaan Keuangan Desa, pengelolaan keuangan desa adalah keseluruhan kegiatan yang meliputi perencanaan, penganggaran, penatausahaan, pelaporan, pertanggungjawaban, dan pengawasan keuangan desa. Efektivitas adalah suatu keadaan yang menunjukkan sejauh mana rencana dapat tercapai. Semakin banyak rencana yang dapat dicapai, semakin efektif pula kegiatan tersebut, sehingga kata efektivitas dapat juga diartikan sebagai tingkat keberhasilan yang dapat dicapai dari suatu cara atau usaha tertentu sesuai dengan tujuan yang hendak dicapai.

Sedangkan efisiensi merupakan perbandingan antara input dan output yang dikaitkan dengan standar kinerja atau sasaran yang sudah ditentukan. Semakin besar rasio, maka semakin tinggi tingkat efisiensinya. Jadi dapat disimpulkan bahwa efektivitas dan efisiensi pengelolaan dana nagari adalah keseluruhan kegiatan yang meliputi perencanaan, penganggaran, penatausahaan, pelaporan, pertanggungjawaban, dan pengawasan keuangan desa yang menunjukkan keadaan atau tingkat keberhasilan suatu pemerintahan desa dalam mencapai rencana yang dapat dicapai dan sesuai dengan standar kinerja atau sasaran yang sudah ditentukan.

\section{Kerangka Pemikiran}

Penelitian ini terkait efektivitas dan efisiensi pengelolaan dana nagari pada nagari di Kabupaten Agam. Dimana pemerintah nagari perlu memperhatikan efektivitas dalam merencanakan anggaran, memperhitungkan efisiensi atas dana yang akan dikelola agar

penggunaan dana naagri dan tujuan adanya dana nagari dapat tercapai maksimal. Serta menggunakan dana tersebut untuk kegiatan yang tepat sasaran, agar penggunaan anggaran tepat guna. Untuk memperjelas kerangka pemikiran penelitian ini, akan disajikan dalam bentuk bagan, seperti pada gambar 1 berikut ini : 


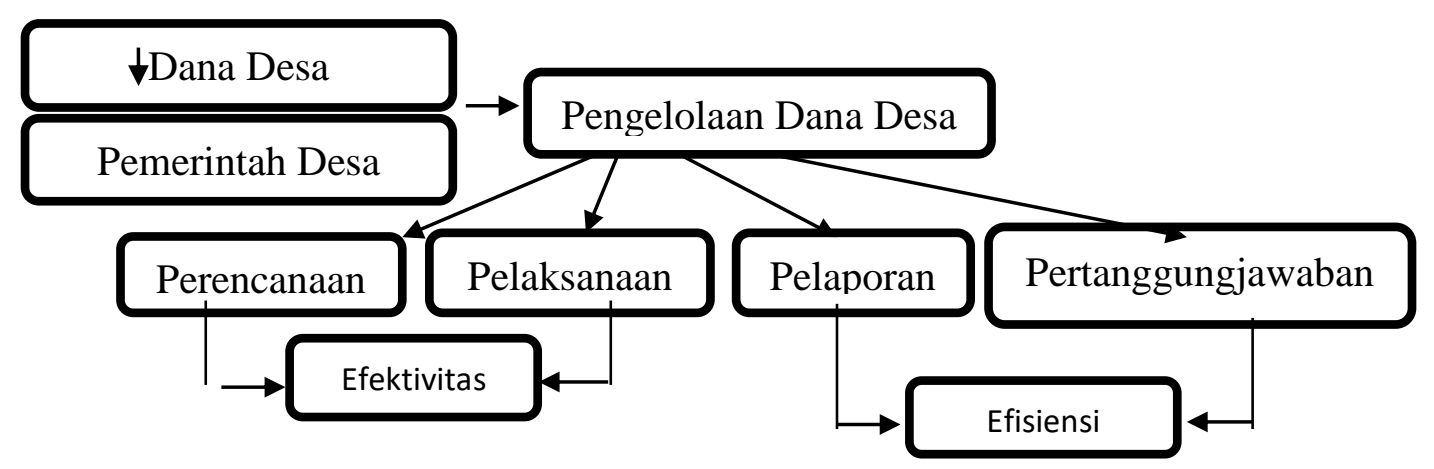

Gambar 1. Kerangka Pemikiran

\section{METODOLOGI PENELITIAN}

\section{Jenis Penelitian}

Penelitian ini menggunakan metode penelitian deskriptif kuantitatif, menurut Rampengan, dkk. (2016) menyatakan bahwa penelitian deskriptif kuantitatif yaitu mendeskripsikan data secara apa adanya dan menjelaskan data atau kejadian tersebut dengan suatu kalimat penjelas secara kuantitatif untuk mendapatkan suatu data yang mendalam dan mengandung makna secara signifikan.

\section{Lokasi Penelitian}

Penelitian ini dilakukan di empat Kecamatan yang ada di Kabupaten Agam yaitu, Kecamatan Matur, Kecamatan Baso, Kecamatan IV Angkek, dan Kecamatan Kamang Magek.

\section{Populasi dan Sampel Penelitian}

Populasi dalam penelitian ini berjumlah 82 (delapan puluh dua) Nagari, sampel dalam penelitian ini berjumlah 17 (tujuh belas) Nagari (terdapat pada tabel 1), dan responden dalam penelitian ini berjumlah 119 (seratus sembilan belas) orang. Metode pengambilan sampel dalam penelitian ini dilakukan dengan menggunakan metode purpusive sampling, yaitu pemilihan sampel dilakukan berdasarkan kriteria yang telah ditetapkan.

Kriteria sampelnya yaitu Nagari yang tidak pernah mendapatkan penghargaan dalam penilaian tentang Pengelolaan Keuangan Nagari tahun 2017 dan tahun 2018, pejabat pemerintahan di lingkungan Nagari serta pihak-pihak yang mengerti/memahami mengenai pengelolaan dana nagari di nagari terkait. Adapun responden penelitian dalam penelitian ini adalah Wali Nagari, perangkat Nagari (sekretaris Nagari, bendahara nagari dan Kaur perencanaan), ketua Badan Permusyawaratan Desa, wakil ketua Badan Permusyawaratan Desa, anggota Badan Permusyawaratan Desa (mewakili salah satu anggota). 


\section{Tabel 1}

Tabel Sampel

\begin{tabular}{|c|c|c|}
\hline No & Nagari & Kecamatan \\
\hline 1 & Panta Pauah & \multirow{5}{*}{ Matur } \\
\hline 2 & Parik Panjang & \\
\hline 3 & Matua Hilia & \\
\hline 4 & Lawang & \\
\hline 5 & Matua Mudiak & \\
\hline 6 & Kamang Mudiak & \multirow{2}{*}{ Kamang Magek } \\
\hline 7 & Kamang Hilia & \\
\hline 8 & Salo & \multirow{4}{*}{ Baso } \\
\hline 9 & Tabek Panjang & \\
\hline 10 & Padang Tarok & \\
\hline 11 & Koto Tinggi & \\
\hline 12 & Panampuang & \multirow{6}{*}{ IV Angkek } \\
\hline 13 & Lambah & \\
\hline 14 & Biaro Gadang & \\
\hline 15 & Balai Gurah & \\
\hline 16 & Ampang Gadang & \\
\hline 17 & Pasia & \\
\hline
\end{tabular}

\section{Jenis Dan Sumber Data}

Jenis data dalam penelitian ini adalah jenis data primer dan data sekunder. Data primer langsung diperoleh dari wali nagari, perangkat nagari, dan BPD yang memahami konteks masalah yang diteliti di Kabupaten Agam terkait informasi yang diberikan guna mengumpulkan informasi dari objek penelitian tersebut. Data sekunder merupakan data yang diperoleh secara tidak langsung atau dari pihak ketiga atau literatur, tulisan dan dokumentasi. Tulisan-tulisan sebagai pembanding dari data yang diperoleh yaitu Undang-Undang Nomor 6 tahun 2014 tentang Desa, Peraturan Pemerintah Nomor 43 tahun 2014 tentang Peraturan Pelaksanaan Undang-Undang Nomor 6 tahun 2014 tentang Desa, dan Peraturan Menteri Dalam Negeri Nomor 113 tahun 2014 tentang Pengelolaan Keuangan Desa.

\section{Instrumen Penelitian}

Instrumen penelitian merupakan alat atau fasilitas yang digunakan oleh peneliti dalam mengumpulkan data agar pekerjaannya lebih mudah dan hasilnya lebih baik, dalam arti lebih cermat, lengkap dan sistematis sehingga lebih mudah diolah (Arikunto, 2010:203). Sedangkan menurut Sugiono (2013:146) instrumen penelitian merupakan suatu alat yang digunakan untuk mengukur fenomena alam maupun sosial yang diamati. Dari penjelasan tersebut dapat disimpulkan bahwa instrumen penelitian digunakan untuk melakukan pengukuran dengan tujuan menghasilkan data yang akurat. Dalam penelitian ini pengujian keakuratan data dari instrumen penelitian menggunakan skala, yaitu menggunakan skala likert. 
Skala likert menurut Sugiono (2013:132) digunakan untuk mengukur sikap, pendapat dan persepsi seseorang atau sekelompok orang tentang fenomena sosial. Dalam penelitian ini, peneliti menggunakan pemberian skor dengan ketentuan sebagai berikut:

$\begin{array}{lll}\text { STB } & \text { : Sangat Tidak Baik } & =1 \\ \text { TB } & \text { : Tidak Baik } & =2 \\ \text { CB } & \text { : Cukup Baik } & =3 \\ \text { B } & \text { : Baik } & =4 \\ \text { SB } & \text { : Sangat Baik } & =5\end{array}$

\section{Teknik Pengumpulan Data}

Menurut Sekaran (2013) pengumpulan data merupakan cara yang digunakan untuk mendapatkan data yang akan diolah menjadi suatu hasil penelitian. Data primer penelitian ini adalah berupa kuesioner yang disebarkan kepada responden penelitian. Sedangkan untuk data sekunder adalah dari laporan realisasi dana nagari yang didapat langsung dari bendahara nagari tempat penelitian dilakukan. Sedangkan menurut Sugiono (2017:137) pengumpulan data merupakan cara yang dilakukan untuk memperoleh data dan keterangan-keterangan yang diperlukan dalam penelitian. Teknik pengumpulan data yang dilakukan penulis dalam penelitian ini adalah:

\section{Kuesinoer}

Data-data diperoleh dengan melakukan penyebaran pertanyaan berupa kuesioner kepada responden yang ditentukan berdasarkan relevansi terhadap topik penelitian yang dilakukan. Daftar pertanyaan mengenai pendapat responden terkait pengelolaan dana nagari.

\section{Dokumentasi}

Pegumpulan data dengan mengumpulkan dokumen-dokumen pemerintahan nagari serta arsiparsip yang ada kaitannya dengan masalah yang akan diteliti. Dimana dalam penelitian ini laporan yang dijadikan sumber yaitu laporan realisasi dana nagari.

\section{Studi kepustakaan}

Pengumpulan data juga dilakukan melalui studi kepustakaan, yaitu data dan informasi diperoleh dengan menelaah berbagai literatur, buku, referensi, dan sebagainya yang digunakan dalam penelitian ini.

\section{Teknik Analisis Data}

Teknik analisis data yang digunakan dalam penelitian ini menggunakan pendekatan penelitian deskriptif. Menurut Sugiyono (2009:206), analisis deskriptif adalah statistik yang digunakan untuk menganalisa data dengan cara mendeskripsikan atau menggambarkan data yang telah terkumpul sebagaimana adanya tanpa bermaksud membuat kesimpulan yang berlaku untuk umum atau generalisasi. Menurut Sekaran (2013:352), analisis deskriptif adalah paradigma yang bertujuan untuk memperoleh informasi tanpa ada maksud dan tujuan untuk membuat kesimpulan tertentu. Dalam penelitian ini dilakukan pengujian validitas dan reliabilitas data. Hal ini dilakukan karena beberapa data yang digunakan merupakan data primer yang harus diuji keabsahannya melalui teknik triangulasi. 


\section{Uji Validitas}

Pengujian validitas menggunakan teknik corrected item-total correlation yaitu dengan cara mengoreksi skor setiap item dengan total skornya. Kriteria valid atau tidak valid adalah bila korelasi $T_{\text {hitung }}$ kurang dari nilai $T_{\text {tabel }}$ dengan tingkat signifikan $\alpha=5 \%$, berarti bunyi pernyataan tidak valid (Ghozali, 2009).

\section{Uji Realibitas}

Keandalan (reliability) pengukuran dibuktikan dengan menguji konsistensi dan stabilitas. Konsistensi menunjukkan seberapa baik item-item yang mengukur sebuah konsep bersatu menjadi sebuah kumpulan. Alfa Cronbach adalah koefisien keandalan yang menunjukkan seberapa baik item dalam suatu kumpulan secara positif berkorelasi satu sama lain. Alfa Cronbach dihitung dalam hal rata-rata interkorelasi antar-item yang mengukur konsep. Semakin dekat Alfa Cronbach dengan 1, semakin tinggi keandalan konsistensi internal (Sekaran, 2006: 177). Semakin dekat koefisien keandalan dengan 1,0 maka semakin baik. Secara umum, keandalan kurang dari 0,6 dianggap buruk, keandalan dalam kisaran 0,7 bisa diterima, dan lebih dari 0,8 adalah baik (Sekaran, 2006:182).

3. Analisis Efektivitas dan Efisieni

a. Rasio Efektivitas

$$
\text { Efektifitas }=\frac{\text { Realisasi belanja nagari }}{\text { Target belanja nagari }} \times 100 \%
$$

Keputusan Menteri Dalam Negeri Nomor 690.900-327 tahun 1996, kriteria tingkat efektivitas sebagai berikut :

1) Jika hasil perbandingan lebih dari $100 \%$, maka dikatakan sangat efektif.

2) Jika hasil perbandingan antara $90 \%$ - 100\%, maka dikatakan efektif.

3) Jika hasil perbandingan antara $80 \%-90 \%$, maka dikatakan cukup efektif.

4) Jika hasil perbandingan antara $60 \%$ - 80\%, maka dikatakan kurang efektif.

5) Jika hasil perbandingan dibawah $60 \%$, maka dikatakan tidak efektif.

b. Rasio Efisiensi

$$
\text { Efisiensi }=\frac{\text { Realisasi belanja nagari }}{\text { Realisasi pendapatan nagari }} \times 100 \%
$$

Keputusan Menteri Dalam Negeri Nomor 690.900-327 tahun 1996, kriteria tingkat efisiensi sebagai berikut :

1) Jika hasil perbandingan lebih dari $100 \%$, maka dikatakan tidak efisien.

2) Jika hasil perbandingan antara $90 \%$ - 100\%, maka dikatakan kurang efisien.

3) Jika hasil perbandingan antara $80 \%-90 \%$, maka dikatakan cukup efisien.

4) Jika hasil perbandingan antara $60 \%-80 \%$, maka dikatakan efisien.

5) Jika hasil perbandingan dibawah $60 \%$, maka dikatakan sangat efisien. 


\section{HASIL DAN PEMBAHASAN}

\section{Efektivitas Pengelolaan Dana Nagari di Satuan Perangkat Nagari}

Dari data yang telah diolah melalui program SPPS dapat diketahui bahwa efektifitas pengelolaan dana desa yang terjadi di kabupaten agam selama tahun 2015-2018 berjalan secara efektif sesuai dengan kriteria yang telah ditentukan dalam keputusan menteri dalam negeri nomor 690.900-327 tahun 1996. Hal ini juga dapat lihat dari uji validitas dan uji reliabitas yang didapatkan dari item kuesioner yang telah disebar pada satuan perangkat desa.

Dimana dari hasil pengolahan data diperoleh hasil valid dan reliabel dari segi proses perencanaan pengelolaan dana desa, dari segi pelaksanaan program yang ada, dari segi penatausahaan laporan keuangan dana desa, dari segi pelaporan kepada pemerintah terkait penggunaan dana desa serta pertanggungjawaban terhadap dana desa yang telah digunakan. Efektivitas serapan anggaran dana desa sangat tergantung pada kapabilitas aparatur nagari dalam pengelolaan keuangan desa (Arza dkk, 2019). Hasil penelitian menunjukkan tingkat pencapaian kinerja keuangan yang efektif. Dan beberapa faktor yang dapat menghambat kegiatan pengelolaan keuangan dana desa di kecamatan Bukit Malintang yaitu SDM/perangkat desa, tingkat partisipasi masyarakat serta informasi perencanaan dan realisasi dana desa.

\section{Efisiensi Pengelolaan Dana Nagari di Satuan Perangkat Nagari}

Efisiensi pengelolaan dana desa sangat diperlukan, untuk mengoptimalkan penggunaan anggaran, dan melihat apakah anggaran atau dana yang digunakan sudah tepat sasaran penyaluran nya atau tidak. Dari data yang telah diperoleh dan dilakukan pengelolaan data, dapat diketahui bahwa secara keseluruhan hasil efisiensi dari setiap desa berbeda-beda, namun secara garis besar dapat diambil kesimpulan bahwa pengelolaan dana desa di kabupaten agam dari tahun 2015-2018 masih tergolong kurang efisien. Hal ini dapat terjadi dikarenakan masih kurang nya proses dalam perihal perencanaan, pelaksanaan, penatausahaan, pelaporan sampai dengan proses pertanggung jawaban.

Masih banyak dari kegiatan yang telah direncanakan diluar ekspektasi mengalami kenaikan biaya, sehingga efisiensi yang seharusnya dicapai tidak terjadi. Disisi lain efisiensi juga tidak dapat tercapai dikarenakan masih banyak nya proyek pemerintah desa yang dilakukan melebihi anggaran yang telah diperkirakan atau mengalami over budgeting, hal ini dapat terjadi jika kebutuhan pemerintah desa masih banyak yang belum terpenuhi, seperti akses jalan yang rusak, infrastruktur yang belum memadai, serta sumber daya alam dan manusia yang terbatas. maka dari itu pemerintah diharapkan dapat berkontribusi untuk melakukan perbaikan yang signifikan.

Hal lainnya yang dapat terjadi adalah masih kurang nya partisipasi masyarakat dalam pembentukan anggaran maupun rancangan kegiatan, serta masih kurang nya pengetahuan dan informasi mengenai pengelolaan keuangan desa. Dari data yang telah diperoleh juga dapat diambil kesimpulan bahwa hampir secara keseluruhan terdapat 14 desa yang memperoleh penilaian kurang efisien dalam pengelolaan dana desa nya.

\section{KESIMPULAN, KETERBATASAN, DAN SARAN \\ Kesimpulan}

1. Tingkat capaian responden dari keseluruhan item pernyataan yang digunakan dalam kuesioner sudah sangat baik dan mampu menjawab permasalahan dalam penelitian ini. Selain itu dari uji validitas dan reliabilitas, secara keseluruhan item pernyataan yang digunakan dalam kuesioner dinyatakan valid serta reliabel yang artinya kuesioner dapat 
dijadikan instrumen penelitian dan jawaban yang diberikan dari masing-masing responden konsisten. Oleh karena itu, dapat disimpulkan bahwa pengelolaan dana nagari pada nagari di Kabupaten Agam telah sesuai dengan Undang-undang Nomor 6 tahun 2014 dan Peraturan Menteri Dalam Negeri Nomor 113 tahun 2014 yang mengatur mengenai pengelolaan keuangan desa.Rendahnya kualitas SDM yang berada pada cabang Unit Syariah terkait dengan Akuntansi dan Akuntabilitas Syariah, mereka mengaku bekerja atas dasar peritah semata dan mengikuti alur yang diarahkan saja tanpa menyadari bahwa sistem syariah dijalankan dari pengetahuan dasar akan syariah dan tanggung jawab syariah sebagai muslim yang baik.

2. Tingkat efektivitas dari tujuh belas desa yang digunakan dalam penelitian dapat dikatakan sudah efektif dengan persentase rata-rata diatas 91\%, dari tujuh belas (17) desa sebagai sampel yang digunakan dapat dikatakan bahwa 14 desa memiliki tingkat pengelolaan dana desa yang efektif, selebihnya dua desa yang tidak dapat diperoleh datanya dikarenakan adanya sedikit permasalahan, sedangkan satu desa tidak lengkap untuk dilakukan pengelolaan dana desanya. Sedangkan tingkat efisiensi penggunaan dan pengelolaan dana desa di tujuh belas (17) desa yang ada diKabupaten Agam, masih kurang efisien. Hal ini dapat dilihat dari masih tingginya rata-rata persentase tingkat efisiensi yang diperoleh yakni sebesar 98\%, hal ini diindikasikan oleh beberapa faktor diantaranya masih kurangnya kesadaran masyarakat terhadap pengelolaan dana desa, kurangnya persiapan dari para perangkat desa maupun seluruh pihak yang terlibat dalam penyusunan anggaran dan pengelolaan dana desa.

\section{Keterbatasan}

1. Sampel yang digunakan hanya sebatas perangkat desa serta badan permusyawaratan desa yang terlibat, selain itu jumlah desa yang dijadikan sebagai objek penelitian hanya tujuh belas (17) dan masih terdapat dua desa yang tidak dapat dilakukan pengelolaan data, dikarenakan data yang ada tidak lengkap serta ada data yang tidak diberikan.

2. Pengukuran dalam penggunaan dana desa hanya menggunakan konsep value for money dan tidak menggunakan konsep yang lainnya, serta hanya menggunakan dua rasio dalam pengukuran yakni efektivitas dan efisiensi tidak menggunakan indikator lain yang dapat dijadikan sebagai teknik pengukuran maupun analisis data.

\section{Saran}

1. Bagi pemerintah daerah di Kabupaten Agam dapat lebih memperhatikan dari pengelolaan dan penyaluran dan desa itu sendiri, selain itu dalam penyusunan maupun proses pengelolaan dana desa, diharapkan para anggota maupun aparatur sipil negara yang bekerja pada kantor kepala desa dapat berkoordinasi dengan banyak pihak maupun masyarakat dalam pengelolaan dana desa sehingga adanya transparansi pengelolaan keuangan.

2. Diharapkan dalam pengelolaan dana desa tetap mengacu kepada ketentuan yang telah diatur dalam undang-undang serta harus sesuai dengan proses pengelolaan dana desa itu sendiri yakni mulai dari perencanaan, pelaksanaan, penatausahaan, pelaporan hingga pertanggungjawaban.

3. Diharapkan penelitian selanjutnya dapat menambah sampel penelitian, serta dapat menggunakan indikator pengukuran lain untuk mengukur pengelolaan dana desa selain rasio efektivitas dan rasio efisiensi. Penelitian selanjutnya juga dapat menambah tahun 
pengamatan serta menambahkan variabel independen lain yang juga dapat digunakan dalam mengukur pengelolaan dana desa itu sendiri.

\section{DAFTAR PUSTAKA}

Afifah, Dian Fitriani, dkk, 2017. Village Independence In Village Funds (A Case of Village Fund Management in Traditional and Modern Villages). Vol. 4 No. 25 : 134-145. Journal Padjadjaran University, Bandung.

Amin, Mauliyanna M, 2017. Efektivitas Penggunaan Anggaran Pendapatan Belanja Desa (APBDes) Tahun 2015 di Desa Pulau Sengkilo Kecamatan Kelayang Kabupaten Indragiri Hulu. Skripsi Universitas Riau, Riau.

Agustin, Henri; Arza, Fefri Indra; Mulyani, Erly; Fitra, Halkadri. (2017). Potret Pertanggung Jawaban dan Pelaporan dan Keuangan Nagari di Kabupaten Pasaman Barat. Jurnal WRA. Vol 5, No 2. Hal 1019-1028.

A Siregar, Fachrul, \&Syam BZ, Fazli, 2017. Analisis Efektifitas dan Efisiensi Pengelolaan Keuangan Desa (Studi Pada Desa di Kabupaten Deli Serdang). Vol. 2 No. 4: pp 93-106.

Arza, F. I., Handayani, D. F., \& Honesty, F. F. (2019). PKM Peningkatan Kemampuan Aparatur Nagari Dalam Mengelola Keuangan Nagari di Kabupaten Padang Pariaman Melalui Pelatihan Pengelolaan Keuangan Desa. Wahana Riset Akuntansi, 7(2).

Badan Pusat Statistik Kabupaten Agam. 2018. Statistik .

Fajarsumbar. 2018. https://www.fajarsumbar.com/2018/11/kiat-indra-catri-sukseskan-dana-desadi.html.Diakses 12 Februari 2019.

Fitri, Nurul,. Deli, Anwar,. Fajri. 2018. Analisis Pengelolaan Dana Desa Dalam Pemberdayaan Ekonomi Masyarakat Melalui Badan Usaha Milik Gampong (BUMG) di Gampong Capa Paloh Kecamatan Padang Tiji Kabupaten Pidie. Vol. 3 No. 4: pp 594-607.

Ghozali, Imam., 2005. Aplikasi Analisis Multivariate dengan program SPSS, Badan Penerbit Universitas Diponegoro, Semarang. , 2009. Aplikas iAnalisis Multivariate dengan Program SPSS. Badan Penerbit Universitas Diponegoro. Semarang. ,2011. Aplikasi Analisis Multivariate dengan Program IBM SPSS 21.Edisi 7. Badan Penerbit Universitas Diponegoro. Semarang. 2013. Aplikasi Analisis Multivariate Dengan Program.Edisi Ketujuh.Badan Penerbit Universitas Diponegoro. Semarang.

Hotimah, Hosnol. 2017. Transparansi dan Akuntabilitas Pemerintah Desa Dalam Pengelolaan Anggaran Pendapatan dan Belanja Desa (APBDes).Skripsi Universitas Muhammadiyah Jember, Surabaya.

https://id.wikipedia.org/wiki/Daftar_kecamatan_dan_kelurahan_di_Kabupaten_Agam. Diakses 21 Februari 2019.

http://kuabaso.blogspot.com/2015/04/gambaran-umum-kecamatan-baso.html. Diakses 27 Februari 2019.

http://rri.co.id/post/berita/464947/ekonomi/bupati_agam_terbaik_dalam_pengelolaan_dana_desa _2017.html. Dikases 21 Februari 2019.

Jensen, M dan Smith Jr. 1984.The Modern Theory of Corporate Finance. New York: McGrawHill. 
Kurnia, R., Sebrina, N, Halmawati. (2019). Akuntabilitas Pengelolaan Dana Desa (Studi Kasus pada Desa-Desa di Wilayah Kecamatan Luhak Nan Duo Kabupaten Pasaman Barat). Jurnal Eksplorasi Akuntansi, 1(1) Seri B, 159-180.

Mardiasmo.2009,Akuntansi Sektor Publik.Yogyakarta : Andi

Matondang. 2009. Validitas dan Reliabilitas Suatu Instrumen Penelitian. Jurnal Tabularasa PPS Unimed. Vol 6 No. 1. Medan.Hal 91-95.

Nurcholis, H. 2011. Pertumbuhan dan Penyelenggaraan Pemerintahan Desa. Jakarta: Erlangga.

Nasution, Imam Ya'muri., 2017. Efektivitas Pengelolaan Keuangan Dana Desa di Kecamatan Bukit Malintang Kabupaten Mandailing Natal Tahun 2016.Skripsi Universitas Sumatera Utara, Sumatera Utara.

Prestisi, Yesiska., 2017. Peranan dan Efektivitas Dana Desa Terhadap Pembangunan Nagari (Studi Kasus : 3 Nagari di Kecamatan Baso Kabupaten Agam).Skripsi Universitas Andalas, Sumatera Barat.

Rorong, Marliyanti, Johny Lumolos, Gustof J. E. Undap, 2017. Efektivitas Penggunaan Dana Desa Dalam Pembangunan di Desa Bango Kecamatan Wori Kabupaten Minahasa Utara Tahun Anggaran 2015. Skripsi Universitas Sam Ratulangi, Manado.

Republik Indonesia. Peraturan Menteri Dalam Negeri Nomor 37 Tahun 2007 tentang Pedoman Pengelolaan Keuangan Desa.

- Peraturan Menteri Dalam Negeri Nomor 113 Tahun 2014 tentang Pengelolaan Keuangan Desa. . Peraturan Pemerintah Nomor 6 Tahun 2014 tentang Dana Desa.

- Peraturan Pemerintah Nomor 43 Tahun 2014 tentang Peraturan

Pelaksanaan UU Nomor 6 Tahun 2014 tentang Desa.

. Keputusan Menteri Dalam Negeri Nomor 690.900-327 Tahun 1966 tentang Kriteria Efektifitas dan Efisiensi.

. Undang-Undang Nomor 6 Tahun 2014 tentang Desa.

Shuha, Khalida., 2018. Analisis Pengelolaan Dana Desa (Studi Kasus Pada Desa-desa Selingkungan Kecamatan Lubuk Alung Kabupaten Padang Pariaman).Jurnal, Universitas Negeri Padang, Sumatera Barat.

Sekaran, Uma., 2006.MetodePenelitianuntukBisnis. Edisi 4.Salemba Empat Jakarta.

Siagian, Sondang P., 2002.Kiat Meningkatkan Produktivitas Kerja. Jakarta: PT Rineka Cipta.

Sujarweni, V. W. 2015.Akuntansi Desa Panduan Tata Kelola Keuangan Desa. Yogyakarta: Pustaka Baru Press.

Sumbarsatu. 2017. http://www.sumbarsatu.com/berita/17342-nagari-tigo-balai-terbaik-ipengelolaan-dana-desa-di-agam. Dikases 21 Februari 2019.

2018.http://www.sumbarsatu.com/berita/19894-bupati-agam-berikan-penghargaan-

kepada-nagari-pengelola-keuangan-terbaik. Diakses 21 Februari 2019

Sugiyono. 2009.MetodePenelitian Kuantitatif dan Kualitatif. Bandung: Alfabet. . 2013. Metode Penelitian Bisnis. Bandung: Alfabet

Tangkilisan, Hesel Nogi. 2005.Manajemen Publik. Gramedia Widia. Jakarta

Yosnofrizal. 2018. http://yosnov.blogspot.com/2018/. Diakses 12 Februari 2019 